\title{
Intravesical Ureterocele
}

National Cancer Institute

\section{Source}

National Cancer Institute. Intravesical Ureterocele. NCI Thesaurus. Code C123237.

A ureterocele that is located entirely within the bladder, and which may be associated with a single system, with the upper pole ureter of a completely duplicated system, or rarely associated with a lower pole ureter. (Adapted from Glassberg KI, Braren V, Duckett JW, Jacobs EC, King LR, Lebowitz RL et al. Suggested terminology for duplex systems, ectopic ureters and ureteroceles. J Urol 1984; 132(6):1153-1154.) 